\title{
AKTIVITAS SITOTOKSIK DAN INDUKSI APOPTOSIS DARI EKSTRAK ETIL ASETAT UIva fasciata DELILE TERHADAP SEL CaSki DAN SEL MCF-7
}

\author{
Cytotoxic Activity and Apoptosis Induction of \\ Ulva fasciata Delile Ethyl Acetate Extract Against \\ CaSki and MCF-7 Cell Lines
}

\author{
Thamrin Wikanta ${ }^{1 \star}$, Mahanie Rasyidin ${ }^{2}$, Lestari Rahayu ${ }^{2}$, dan Asri Pratitis ${ }^{1}$ \\ ${ }^{1}$ Balai Besar Penelitian dan Pengembangan Pengolahan Produk dan Bioteknologi Kelautan dan Perikanan, \\ Balitbang KP, KKP. Jl. K.S. Tubun Petamburan VI, Jakarta Pusat 10260 \\ ${ }^{2}$ Fakultas Farmasi - Universitas Pancasila, Jakarta \\ * Korespondensi Penulis: thamrin_wikanta@yahoo.com
}

\begin{abstract}
ABSTRAK
Berbagai senyawa produk alam kelautan menunjukkan aktivitas farmakologi dan berguna sebagai senyawa panduan obat, terutama untuk melawan penyakit-penyakit seperti kanker, AIDS, arthritis, dan lainnya. Salah satu biota laut yang berpotensi sebagai antitumor adalah rumput laut Ulva fasciata Delile. Di Indonesia, ada dua jenis kanker yang paling banyak terjadi yaitu kanker payudara dan kanker serviks. Telah dilakukan penelitian tentang uji apoptosis dari 9 fraksi ekstrak etil asetat Ulva fasciata Delile terhadap dua jenis sel lestari yaitu sel CaSki (sel kanker serviks) dan sel MCF-7 (sel kanker payudara). Uji sitotoksik menggunakan metode neutral red assay yang dilanjutkan dengan uji apoptosis masing-masing fraksi menggunakan Annexin V. Hasil uji sitotoksik terhadap sel CaSki menunjukkan nilai IC ${ }_{50}$ dari Fraksi F1-F9 berkisar antara 18,58$31,54 \mu \mathrm{g} / \mathrm{ml}$. Persentase apoptosis terhadap sel CaSki oleh Fraksi F1-F9 berkisar antara 2,603,92\%. Persentase apoptosis terhadap sel MCF-7 oleh Fraksi F1-F9 berkisar antara 4,43-12,93\%. Hasil penelitian menunjukkan bahwa setiap fraksi etil asetat mampu menginduksi apoptosis terhadap sel CaSki dan MCF-7 dan bekerja lebih potensial terhadap sel MCF-7 daripada terhadap sel Caski.
\end{abstract}

KATA KUNCl: $\quad$ apoptosis, ekstrak etil asetat, Ulva fasciata Delile, CaSki (sel kanker serviks), MCF-7 (sel kanker payudara)

\begin{abstract}
A lot of marine natural compounds showed pharmacological activity and can be used as a drug lead compound, especially against cancer, AIDS, arthritis, etc. One of marine organisms that have antitumor potency is Ulva fasciata Delile algae. In Indonesia, there are two kinds of cancer incident that mostly happened, i.e. breast and cervical cancers. It has already done a research on the apoptosis assay of 9 fraction of Ulva fasciata Delile ethyl acetate extracts against two kinds of cell line, i.e. CaSki (cervical cancer) and MCF7 (breast cancer). The cytotoxic assay was carried out by neutral red assay method followed by apoptosis assay on each fraction using Annexine $V$. Result of cytotoxic assay against CaSki cell line showed that the $I C_{50}$ value of Fractions F1-F9 were between 18.58-31.54 $\mathrm{mg} / \mathrm{ml}$. Apoptosis percentage against CaSki cell line by Fraction F1-F9 were between 2.60-3.92\%. Apoptosis percentage against MCF-7 cell line by Fraction F1-F9 were between 4.43-12.93\%. The result showed that each ethyl acetate fraction was able to induce apoptosis against CaSki and MCF-7 cell lines and worked more potentially against MCF-7 than CaSki cell line.
\end{abstract}

KEYWORDS: $\quad$ apoptosis, ethyl acetate extract, Ulva fasciata Delile, CaSki (cervical cancer), MCF-7 (breast cancer) 


\section{BAHAN DAN METODE}

\section{Bahan}

Alga Ulva fasciata Delile dipanen dari zona pasang surut pantai Binuangeun, Banten Selatan. Sel CaSki diperoleh dari Institut Sains Biology, Fakultas Biologi dan Sains Universitas Malaya. Sel ini merupakan sel epitel serviks, dikultur dalam media RPMI-1640 (Roswell Park Memorial Institute) dengan kecepatan aliran $\mathrm{CO}_{2} 5 \%$ untuk mempertahankan buffer bikarbonat HEPES (N-(2-hydroxyethyl) piperazine-1ethanesulfonic acid) agar mencapai $\mathrm{pH}$ pertumbuhan sel yang optimal. Penanganan sel dilakukan dalam laminar dengan standar biosafety level 2 (ATCC, 2010a). Sel Michigan Cancer Foundation-7 (MCF-7) diperoleh dari Institut Sains Biology, Fakultas Biologi dan Sains Universitas Malaya. Sel ini merupakan sel kanker payudara, dikultur dalam media RPMI 1640 dengan kecepatan aliran $\mathrm{CO}_{2} 5 \%$ untuk mempertahankan buffer bikarbonat HEPES agar mencapai $\mathrm{pH}$ pertumbuhan sel yang optimal. Penanganan sel dilakukan dalam laminar dengan standar biosafety level 2 (ATCC, 2010 ${ }^{\text {b }}$.

\section{Pembuatan Fraksi Ekstrak Etil Asetat Ulva fasciata Delile}

Sebanyak $10 \mathrm{~kg}$ Ulva fasciata Delile segar setelah dibersihkan dari kotoran pasir dan jenis rumput laut lainnya, lalu dimaserasi dalam $10 \mathrm{~L}$ pelarut etil asetat teknis selama $3 \times 24$ jam di dalam jerigen plastik tahan bahan kimia, disertai pengadukan dengan cara menggoncang jerigen berulang kali setiap hari agar proses ekstraksi berlangsung cepat dan larutan homogen. Ekstrak disaring menggunakan kertas Whatman no. 1, lalu dilakukan evaporasi pelarut hingga didapatkan ekstrak kental bentuk pasta,
$\mathrm{DCM}=50 \%: 50 \%), \mathrm{F} 3$ (DCM 100\%), F4 (DCM : EA $=75 \%: 25 \%), F 5(D C M: E A=50 \%: 50 \%), F 6(D C M$ : $E A=25 \%: 75 \%), F 7$ (EA 100\%), F8 (ET 100\%), F9 (ME 100\%). Filtrat yang diperoleh dipekatkan menggunakan rotavapor dan kemudian dikeringkan menggunakan gas $\mathrm{N}_{2}$.

\section{Uji Sitotoksik Fraksi Ulva fasciata Delile terhadap sel CaSki}

Uji sitotoksik merupakan uji kuantitatif menggunakan mikroplate sumuran 96, dalam hal ini menggunakan seri dosis 10,20, dan $30 \mathrm{ì} \mathrm{g} / \mathrm{ml}$ dengan ulangan tiga kali, dan menggunakan DMSO sebagai kontrol negatif. Hasil absorban yang di dapat digunakan untuk menghitung inhibisi pertumbuhannya, dilanjutkan dengan penghitungan $\mathrm{IC}_{50}$. Dimasukkan 150 ì I suspensi sel ke dalam masing-masing well, kemudian diinkubasi dalam inkubator $\mathrm{CO}_{2} 5 \%$ pada suhu $37^{\circ} \mathrm{C}$ selama 12 jam. Sebanyak 150 ì I larutan sampel uji dimasukan ke dalam masing-masing well dengan dosis 10, 20, dan 30 ì l/ml. Sebanyak 150 ì DMSO dimasukan sebagai kontrol negatif. Sel yang berada di dalam sumuran kemudian diinkubasi dalam inkubator $\mathrm{CO}_{2} 5 \%$ pada suhu $37^{\circ} \mathrm{C}$ selama 48 jam dan diamati. Selanjutnya medium kultur dibuang dan ditambahkan 150 ì I neutral red pada setiap well kemudian diinkubasi lagi dalam inkubator $\mathrm{CO}_{2} 5 \%$ pada suhu $37^{\circ} \mathrm{C}$ selama 2 jam. Medium kultur lalu dibuang dan well dicuci dengan PBS, kemudian ditambahkan sebanyak 300 i I SDS 1\% dan diinkubasi lagi dalam inkubator $\mathrm{CO}_{2} 5 \%$ pada suhu $37^{\circ} \mathrm{C}$ selama 30 menit. Setelah selesai inkubasi, suspensi sel diukur dengan menggunakan ELISA Plate Reader pada panjang gelombang $492 \mathrm{~nm}$ sehingga dapat diketahui berapa sel yang hidup dan berapa persentase inhibisinya. Persentase inhibisi sel untuk setiap konsentrasi dapat dihitung dengan menggunakan rumus:

(Absorpsi kontrol negatif-Absorpsi larutan sampel uji)

$\%$ Inhibisi sel $=$ $\times 100 \%$

Absorpsi kontrol negatif

kemudian ekstrak dibekukan dan selanjutnya dikeringkan sempurna menggunakan alat pengering beku (freeze dryer). Sebanyak 1,005 g ekstrak etil asetat Ulva fasciata Delile difraksinasi menggunakan kromatografi kolom dengan fasa diam Silika dan pelarut pengelusi n-heksan (HE), diklormetan (DCM), etil asetat (EA), etanol (ET), dan metanol (ME), dengan perbandingan tertentu agar mendapatkan gradien polaritas meningkat, menjadi 9 fraksi. Semua fraksi yang diuji meliputi: F1 (HE 100\%), F2 (HE :

\section{Uji Apoptosis dengan Annexin V}

Dibuat binding buffer dengan cara melarutkan binding buffer dalam air suling (1:4). Sel dicuci dengan PBS $1 \mathrm{ml}$, disentrifus pada $1000 \mathrm{rpm}$ selama 10 menit kemudian supernatan dibuang. Sel disuspensikan kembali dalam binding buffer (500 ì I), disentrifus pada 1000 rpm selama 10 menit kemudian supernatan dibuang. Ke dalam sel ditambahkan sebanyak 3 ì । Annexin V-FITC dan 7 ì I Propidium lodide, dicampur 
dan diinkubasi selama 10 menit pada suhu kamar ditempat yang gelap. Dilakukan analisa dengan Flowcytometry (Calbiochem, 2010).

\section{Pengolahan Data}

Data hasil uji sitotoksik dan uji apoptosis diolah dengan metode regresi linier berdasarkan persen inhibisi pertumbuhan sel CaSki versus dosis yang digunakan. Nilai $\mathrm{IC}_{50}$ diperoleh dari persamaan garis tersebut dengan memasukkan nilai 50\% kematian. Sedangkan nilai persentase apoptosis dan nekrosis disajikan berdasarkan data keluaran dari flowcytometry.

\section{HASIL DAN BAHASAN}

\section{Fraksi Ekstrak Etil Asetat Ulva fasciata Delile}

Hasil fraksinasi dari 1,005 g ekstrak etil asetat Ulva fasciata Delile menggunakan pelarut pengelusi yang sesuai dengan tingkat kepolaran meningkat disajikan pada Tabel 1.

\section{Hasil Uji Sitotoksik Fraksi Ekstrak Etil Asetat Ulva fasciata Delile Terhadap Sel CaSki}

Hasil uji sitotoksik menggunakan mikroplate sumuran 96 merupakan uji kuantitatif. Hasil perhitungan dari nilai absorbansi yang didapatkan menghasilkan nilai inhibisi pertumbuhan dan nilai $I_{50}$ sebagaimana disajikan pada Tabel 2. Nilai inhibisi pertumbuhan didapatkan berdasarkan perhitungan dengan metode neutral red assay. Sel yang hidup menyerap neutral red yang terkonsentrasi di dalam lisosom sel. Sehingga protein assay adalah cara pengukuran viabilitas sel secara tidak langsung karena ia mengukur kandungan protein dari sel-sel hidup yang tersisa setelah pencucian wadah yang digunakan untuk percobaan. Assay neutral red adalah pemeriksaan kolorimetrik yang menyerap pewarnaan lisosom fungsional (Fotakis \& Timbrell, 2005).

Apabila dilihat dari persen inhibisinya pada masing-masing fraksi, pada dosis terendah (10 ì g/ $\mathrm{ml}$ ) menunjukkan nilai kurang dari 50\%. Berdasarkan penelitian yang dilakukan oleh Carballo et al. (2002), nilai tersebut diklasifikasikan pada tahap inhibisi

Tabel 1. Fraksi ekstrak etil asetat Ulva fasciata Delile hasil elusi dengan kromatografi kolom

Table 1. Fraction of Ulva fasciata Delile ethyl acetate extract eluted by chromatography column

\begin{tabular}{cccrc}
\hline \multirow{2}{*}{$\begin{array}{c}\text { Fraksil } \\
\text { Fraction }\end{array}$} & $\begin{array}{c}\text { Pengelusil } \\
\text { Eluent }\end{array}$ & $\begin{array}{c}\text { Rasio Pengelusil } \\
\text { Eluent ratio (\%) }\end{array}$ & $\begin{array}{c}\text { EkstraklExtract } \\
\text { Weight (mg) }\end{array}$ & $\begin{array}{c}\text { Persen/ } \\
\text { Percent (\%) }\end{array}$ \\
\hline F1 & n-hexane/Dichlormethane & $100 / 0$ & 9.5 & 0.95 \\
F2 & n-hexane/Dichlormethane & $50 / 50$ & 6.8 & 0.68 \\
F3 & Dichlormethane/Ethyl acetate & $100 / 0$ & 7.3 & 0.73 \\
F4 & Dichlormethane/Ethyl acetate & $75 / 25$ & 35.5 & 3.53 \\
F5 & Dichlormethane/Ethyl acetate & $50 / 50$ & 5.7 & 0.57 \\
F6 & Dichlormethane/Ethyl acetate & $25 / 75$ & 4.2 & 0.42 \\
F7 & Dichlormethane/Ethyl acetate & $0 / 100$ & 4.2 & 0.42 \\
F8 & Ethyl acetate/Ethanol & $0 / 100$ & 15.4 & 1.53 \\
F9 & Ethanol/Methanol & $0 / 100$ & 7.7 & 0.77 \\
\hline & Total & & 96.3 & 9.6 \\
\hline
\end{tabular}

Hasil elusi melalui kolom menghasilkan jumlah ekstrak sebanyak 96,3 mg atau 9,6\%. Sebagian besar dari ekstrak tidak dapat terelusi oleh pelarut organik yang berarti bahwa senyawa tersebut adalah senyawa anorganik, yang kemungkinan besar adalah garamgaram anorganik atau garam $\mathrm{NaCl}$. Terlihat bahwa fraksi 4 yaitu elusi dengan campuran DCM/EA (75\%/ 25\%) menghasilkan jumlah ekstrak terbanyak sebesar $35,5 \mathrm{mg}$ atau $3,53 \%$. Selanjutnya yaitu fraksi 8 , elusi dengan etanol $100 \%$ menghasilkan jumlah ekstrak sebesar $15,4 \mathrm{mg}$ atau 1,53\%. Fraksi-fraksi yang lain jumlah ekstraknya $<1 \%$. pertumbuhan yang lemah (tidak aktif). Pada F8 (fraksi etanol) didapatkan nilai inhibisi yang negatif. Nilai negatif tersebut masuk dalam kategori tidak ada inhibisi pertumbuhan (tidak aktif). Pada dosis tertinggi didapatkan nilai inhibisi $50-100 \%$ yang di klasifikasikan memiliki inhibisi yang sedang hingga tinggi. Pada nilai ini dapat dikatakan bahwa ektrak tersebut aktif dan memiliki efek menginhibisi pertumbuhan sel (Carballo et al., 2002). Hasil uji sitotoksik dengan metoda neutral red assay menunjukkan nilai $I C_{50}$ dari masing-masing fraksi kurang dari $30 \mathrm{ìg} / \mathrm{ml}$. Berdasarkan kriteria dari 
Tabel 2. Hubungan antara dosis dengan \% Inhibisi dan nilai IC ${ }_{50}$ dari sembilan fraksi etil asetat Ulva fasciata Delile terhadap sel CaSki

Table 2. Relationship of extract dosage with inhibition percentage and IC ${ }_{50}$ value of Ulva fasciata Delile ethyl acetate fraction against CaSki cell line

\begin{tabular}{|c|c|c|c|c|}
\hline $\begin{array}{l}\text { Fraksil } \\
\text { Fraction }\end{array}$ & $\begin{array}{c}\text { Dosis/Dose } \\
(\mu \mathrm{g} / \mathrm{ml})\end{array}$ & $\begin{array}{c}\text { Inhibisil } \\
\text { Inhibition (\%) }\end{array}$ & $\begin{array}{c}\text { Regresi Linierl } \\
\text { Linear Regression }\end{array}$ & $\mathrm{IC}_{50}(\mu \mathrm{g} / \mathrm{mI})$ \\
\hline \multirow{3}{*}{ F1 } & 10 & 16.38 & \multirow{3}{*}{$\begin{array}{c}y=4.093+2.065 x \\
r=0.670\end{array}$} & \multirow{3}{*}{22.23} \\
\hline & 20 & 62.12 & & \\
\hline & 30 & 57.68 & & \\
\hline \multirow{3}{*}{$\mathrm{F} 2$} & 10 & 9.56 & \multirow{3}{*}{$\begin{array}{c}y=-15.12+2.064 x \\
r=0.897\end{array}$} & \multirow{3}{*}{31.54} \\
\hline & 20 & 18.09 & & \\
\hline & 30 & 50.85 & & \\
\hline \multirow{3}{*}{ F3 } & 10 & 22.53 & \multirow{3}{*}{$\begin{array}{c}y=3.756+2.099 x \\
r=0.967\end{array}$} & \multirow{3}{*}{22.03} \\
\hline & 20 & 50.17 & & \\
\hline & 30 & 64.51 & & \\
\hline \multirow{3}{*}{$\mathrm{F} 4$} & 10 & 30.72 & \multirow{3}{*}{$\begin{array}{c}y=16.27+1.552 x \\
r=0.985\end{array}$} & \multirow{3}{*}{21.73} \\
\hline & 20 & 49.49 & & \\
\hline & 30 & 61.77 & & \\
\hline \multirow{3}{*}{ F5 } & 10 & 31.06 & \multirow{3}{*}{$\begin{array}{c}y=5.916+2.372 x \\
r=0.989\end{array}$} & \multirow{3}{*}{18.59} \\
\hline & 20 & 50.51 & & \\
\hline & 30 & 78.5 & & \\
\hline \multirow{3}{*}{ F6 } & 10 & 3.07 & \multirow{3}{*}{$\begin{array}{c}y=-18.66+2.952 x \\
r=0.827\end{array}$} & \multirow{3}{*}{23.26} \\
\hline & 20 & 55.97 & & \\
\hline & 30 & 62.12 & & \\
\hline \multirow{3}{*}{$\mathrm{F} 7$} & 10 & 29.01 & \multirow{3}{*}{$\begin{array}{c}y=14.33+1.280 x \\
r=0.939\end{array}$} & \multirow{3}{*}{27.87} \\
\hline & 20 & 36.18 & & \\
\hline & 30 & 54.61 & & \\
\hline \multirow{3}{*}{ F8 } & 10 & -17.41 & \multirow{3}{*}{$\begin{array}{c}y=-46.65+3.515 x \\
r=0.921\end{array}$} & \multirow{3}{*}{27.49} \\
\hline & 20 & 35.49 & & \\
\hline & 30 & 52.9 & & \\
\hline \multirow{3}{*}{ F9 } & 10 & 33.11 & \multirow{3}{*}{$\begin{array}{c}y=-4.546+2.918 x \\
r=0.798\end{array}$} & \multirow{3}{*}{18.69} \\
\hline & 20 & 36.86 & & \\
\hline & 30 & 91.47 & & \\
\hline
\end{tabular}

American National Cancer Institute, batas $\mathrm{IC}_{50}$ untuk ekstrak kasar yang menjanjikan untuk diteliti lebih lanjut adalah kurang dari 30 ì g/ml (Torres et al., 2005). Berdasarkan hasil uji sitotoksik tersebut maka dipilih dosis $25 \mathrm{ì} \mathrm{g/ml} \mathrm{sebagai} \mathrm{dosis} \mathrm{untuk} \mathrm{meneliti}$ mekanisme kerja dari masing-masing fraksi ekstrak etil asetat.

\section{Hasil Uji Apoptosis Menggunakan Annexin V}

Prinsip dari Annexin V-FITC Apoptosis Kit II adalah menggunakan Annexin $\mathrm{V}$ yang berkonjugasi dengan FITC untuk mengikat phosphatidylserine pada permukaan sel yang mengalami apoptosis. Propidium iodide digunakan untuk membedakan sel yang hidup, apoptosis dan nekrosis (Calbiochem, 2010).

Dari pembacaan flowcytometry diperoleh hasil persentase kematian sel secara apoptosis maupun nekrosis, serta jumlah sel yang tetap hidup. Kematian sel akibat nekrosis dapat diakibatkan oleh kesalahan dalam pengerjaan. Hasil yang diperoleh, menunjukkan bahwa persentase kematian sel akibat apoptosis lebih besar daripada nekrosis. Hal ini menunjukkan bahwa masing-masing fraksi dari ekstrak etil asetat Ulva fasciata Delile dapat menginduksi apoptosis pada sel CaSki dan MCF-7. Nilai persentase apoptosis, nekrosis, dan sel yang hidup dapat dilihat pada Tabel 3. Beberapa data keluaran dari instrumen flowcytometry disajikan pada Gambar 1-4 terlampir.

Pada sel CaSki, persentase apoptosis paling tinggi pada fraksi F8 (etanol) sebesar 3,92\%. Pada sel MCF7, fraksi yang menginduksi apoptosis yang terbesar adalah fraksi F2 (campuran antara $n$-heksan dengan diklormetan) sebesar 12,93\%. Memperhatikan nilai persentase apoptosisnya maka fraksi ekstrak etil asetat bekerja lebih baik terhadap sel MCF-7 (kanker payudara) daripada terhadap sel CaSki (kanker 
Tabel 3. Pengaruh perlakuan 9 fraksi ekstrak etil asetat $U$. fasciata Delile terhadap persentase apoptosis dan nekrosis dari jumlah sel CaSki dan MCF-7 yang hidup.

Table 3. Effect of 9 fractions of $U$. fasciata Delile extract treatment on the apoptotic and necrotic percentage of life CaSki and MCF-7 cell lines

\begin{tabular}{ccccc}
\hline $\begin{array}{c}\text { Sel Lestaril } \\
\text { Cell Line }\end{array}$ & $\begin{array}{c}\text { Fraksil } \\
\text { Fraction }\end{array}$ & $\begin{array}{c}\text { Sel Hidupl } \\
\text { Life Cell (\%) }\end{array}$ & $\begin{array}{c}\text { Apoptosisl } \\
\text { Apoptotic (\%) }\end{array}$ & $\begin{array}{c}\text { Nekrosisl } \\
\text { Necrotic (\%) }\end{array}$ \\
\hline \multirow{6}{*}{ CaSki } & F1 & 96.06 & 2.82 & 0.15 \\
& F2 & 95.59 & 3.59 & 0.07 \\
& F3 & 96.58 & 2.67 & 0.20 \\
& F4 & 96.49 & 2.60 & 0.15 \\
& F5 & 96.16 & 3.03 & 0.19 \\
& F6 & 95.64 & 2.91 & 0.42 \\
& F7 & 95.11 & 3.79 & 0.25 \\
& F8 & 94.84 & 3.92 & 0.26 \\
& F9 & 95.41 & 3.19 & 1.64 \\
& Kontrol/Control (-) & 93.78 & 3.77 & 0.53 \\
& Kontrol/Control (+) & 70.37 & 4.85 & 1.59 \\
\hline \multirow{5}{*}{ MCF-7 } & F1 & 87.58 & 9.36 & 0.47 \\
& F2 & 83.75 & 12.93 & 0.40 \\
& F3 & 84.14 & 10.78 & 0.59 \\
& F4 & 91.12 & 4.43 & 0.20 \\
& F5 & 85.64 & 9.00 & 0.34 \\
& F6 & 86.03 & 8.74 & 0.52 \\
& F7 & 85.69 & 10.49 & 0.79 \\
& F8 & 85.16 & 10.82 & 0.44 \\
& F9 & 81.51 & 12.81 & 0.45 \\
& Kontrol/Control (-) & 91.73 & 4.39 & 0.30 \\
& Kontrol/Control (+) & 67.26 & 18.19 & 1.55 \\
\hline
\end{tabular}
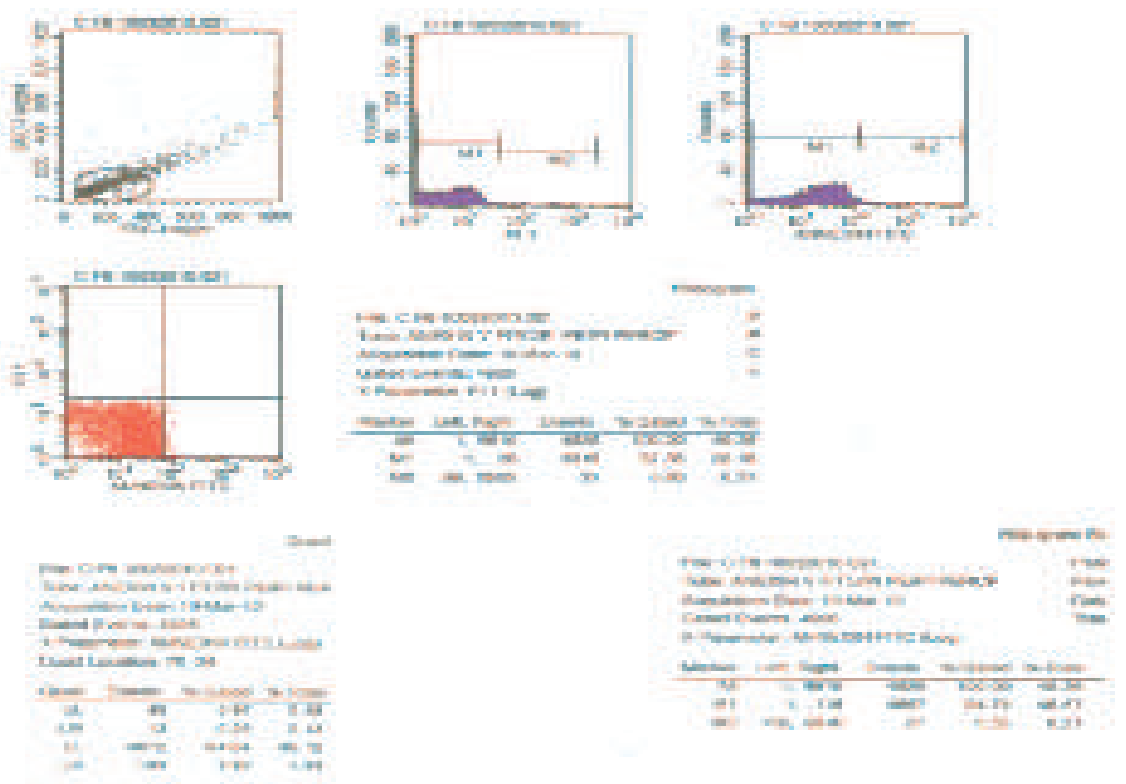

Gambar 1. Hasil uji apoptosis fraksi F8 ekstrak etil asetat Ulva fasciata Delile terhadap sel tumor cerviks (CaSki). Nilai apoptosis 3,92\%. Nilai nekrosis 0,26\%.

Figure 1. Result of apoptotic test of Ulva fasciata Delile ethyl acetate extract F8 fraction against cervix tumor cell line (CaSki). Apoptotic value of 3.92\%. Necrotic value of $0.26 \%$. 

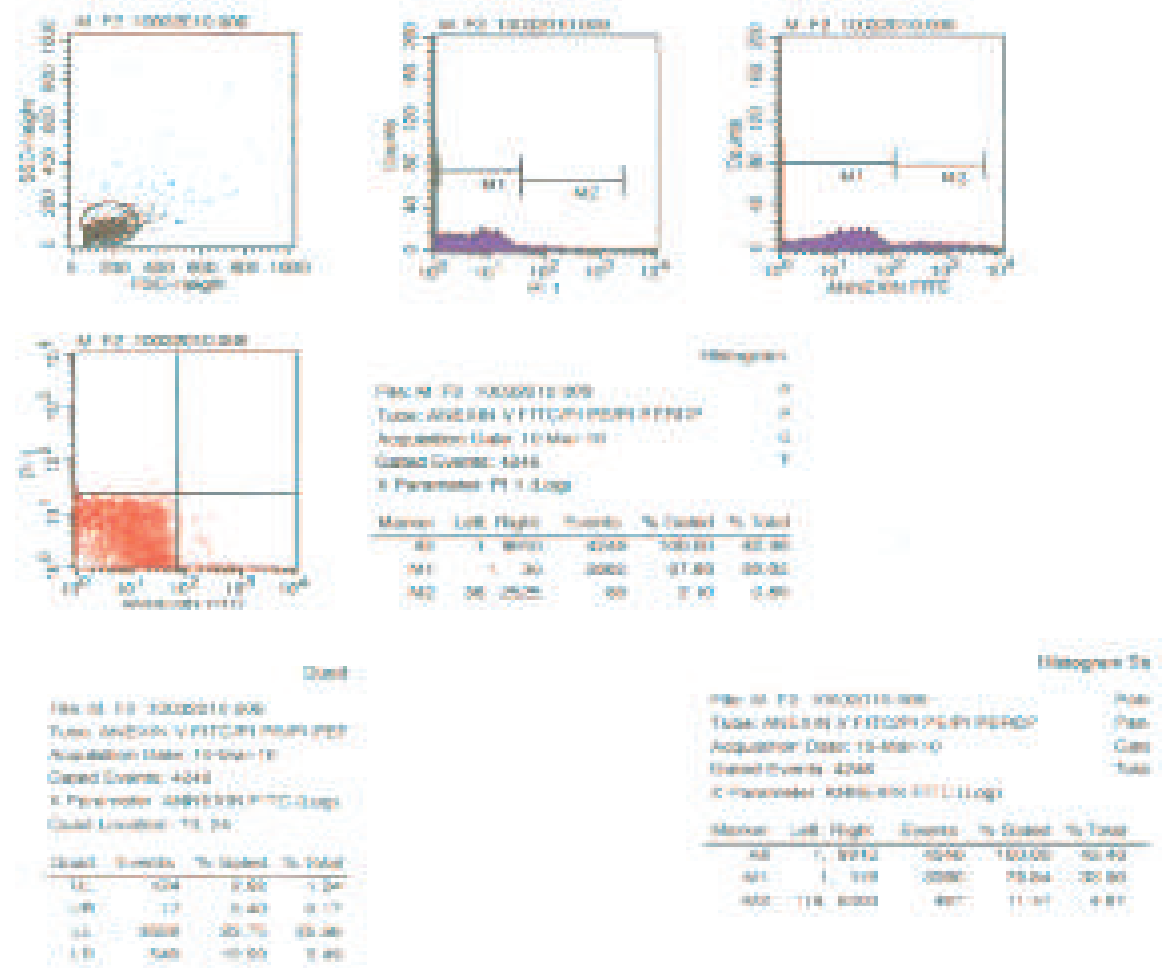

Gambar 2. Hasil uji apoptosis fraksi F2 ekstrak etil asetat Ulva fasciata Delile terhadap sel tumor payudara (MCF-7). Nilai apoptosis $12,93 \%$. Nilai nekrosis $0,40 \%$.

Figure 2. Result of apoptotic test of Ulva fasciata Delile ethyl acetate extract F2 farction against breast tumor cell line (MCF7). Apoptotic value of $12.93 \%$. Necrotic value of $0.40 \%$.
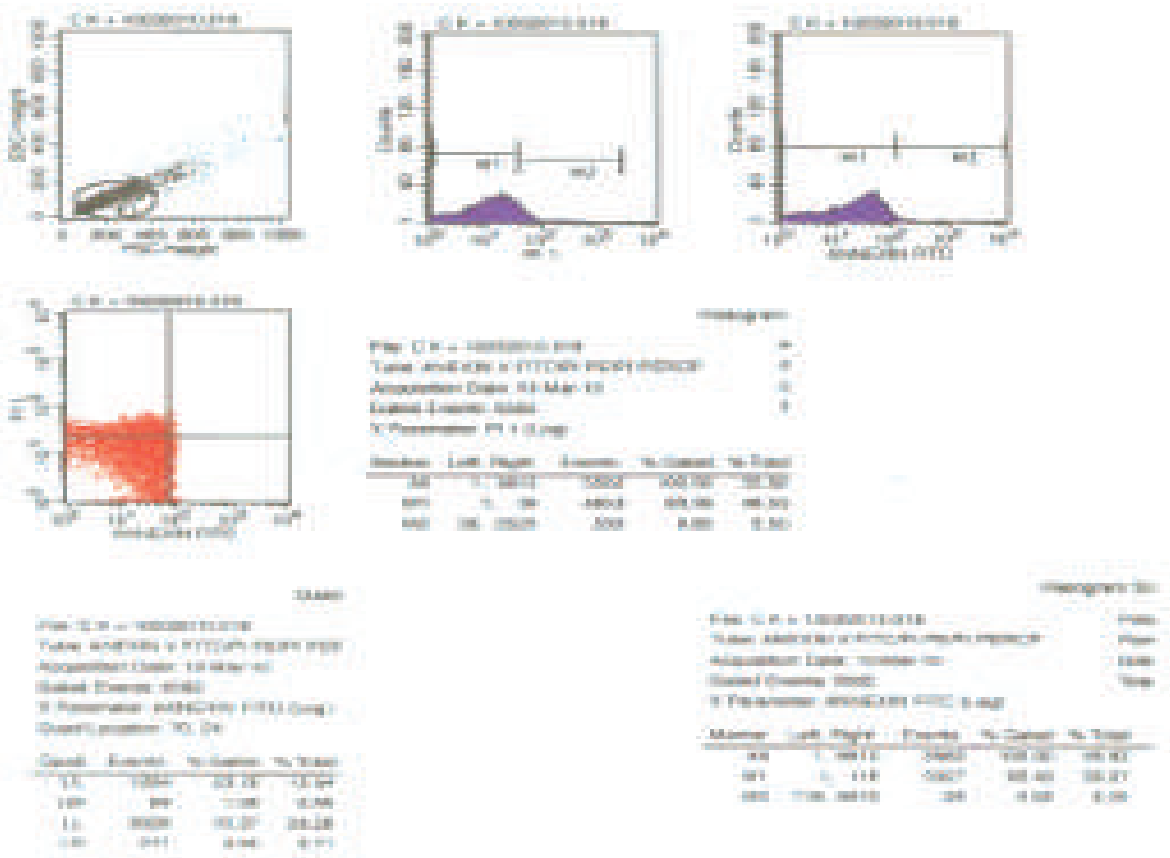

Gambar 3. Hasil uji apoptosis kontrol positif (Doxorubicin) terhadap sel tumor cerviks (CaSki). Nilai apoptosis $4,85 \%$. Nilai nekrosis $1,59 \%$.

Figure 3. Result of apoptotic test of positive control (Doxorubicin) against cervix tumor cell line (CaSki). Apoptotic value of $4.85 \%$. Necrotic value of $1.59 \%$. 

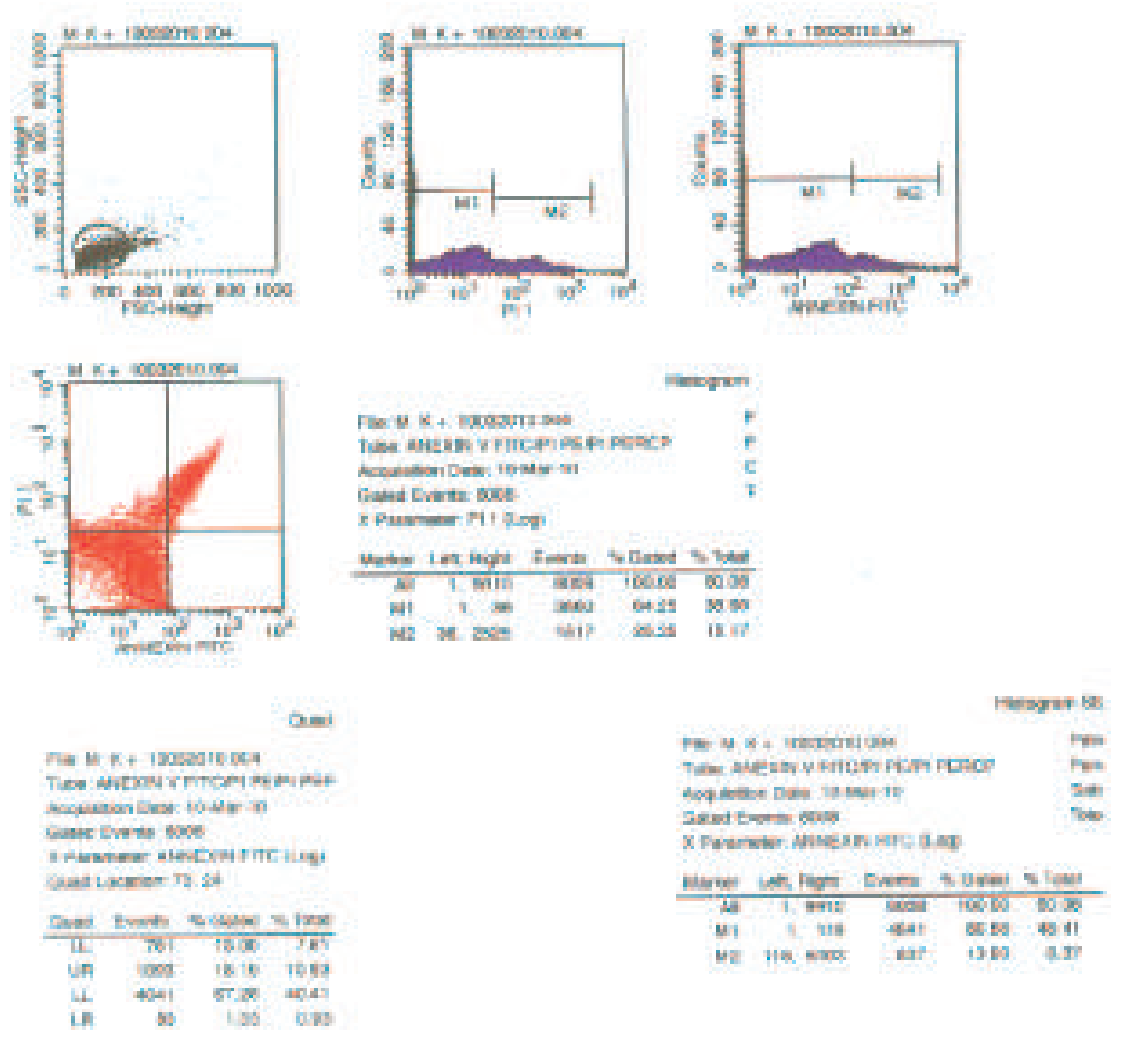

Gambar 4. Hasil uji apoptosis kontrol positif (Doxorubicin) terhadap sel tumor payudara (MCF7). Nilai apoptosis $18,19 \%$. Nilai nekrosis 1,55\%.

Figure 4. Result of apoptotic test of positive control (Doxorubicin) against breast tumor cell line (MCF7). Apoptotic value of $18.19 \%$. Necrotic value of $1.55 \%$.

serviks). Ini menunjukkan bahwa fraksi etil asetat lebih potensial digunakan dalam pengobatan kanker payudara.

Apoptosis menginduksi berbagai perubahan dalam membran plasma termasuk perubahan permeabilitas dan lipid membran. Selama apoptosis terjadi perubahan utama pada lipid membran di mana phospatidilserine (PS) berpindah posisi dari membran internal ke eksternal. Phospatidilserine (PS) berikatan dengan Annexin $\mathrm{V}$ dan perubahan ini dapat diamati dengan inkubasi sel dengan Annexin V. Annexin V adalah protein yang memiliki afinitas tinggi terhadap phosfolipid yang bermuatan negatif dengan adanya ion $\mathrm{Ca}^{2+}$. Sel dinkubasi dengan Annexin $\mathrm{V}$ yang telah dikonjugasi dengan fluorokrom yang sesuai, biasanya dengan penambahan Propidium lodide (PI) untuk membedakan sel-sel yang telah kehilangan integritasnya pada membran plasma (Ormerod, 2000).

Uji apoptosis pada penelitian ini menggunakan Annexin $\vee$ dengan konsentrasi masing-masing fraksi 25 ì g/ml. Konsentrasi ini diambil karena dari uji sitotoksik nilai yang didapat berkisar antara 22,2331,54 ì $\mathrm{g} / \mathrm{ml}$. Oleh sebab itu dipilih dosis 25 ì g/ml untuk menyeragamkan konsentrasi dari fraksi satu sampai sembilan. Dosis tersebut dipilih karena dapat mewakili nilai $I C_{50}$ dari masing-masing fraksi ekstrak etil asetat dan tidak melebihi batas dari American National Cancer Institute yang menyatakan bahwa pada dosis yang kurang dari $30 \mathrm{ì} \mathrm{g} / \mathrm{ml}$ adalah dosis yang menjanjikan untuk diteliti lebih lanjut. Sebagai kontrol negatif digunakan DMSO $2 \%$ dan Doxorubicin sebagai kontrol positif. Uji apoptosis ini menggunakan dua cell line, yaitu sel CaSki (sel kanker serviks) dan MCF-7 (sel kanker payudara).

Pada sel hidup yang normal, phosphatidylserine (PS) terletak pada permukaan sitoplasmik pada sel membran. Selama induksi apoptosis, perubahan yang cepat terjadi pada fosfolipid dalam sel yang menyebabkan pembongkaran PS pada permukaan sel. Deteksi in vitro dari PS eksternal dapat diperoleh dari interaksi dengan antikoagulan Annexin V. Dengan kehadiran kalsium, kemampuan ikatan antara annexin V dengan PS terjadi sangat cepat. Translokasi PS pada permukaan sel mendahului pembongkaran nuklear, fragmentasi DNA dan kemunculan apoptosis menjadikan ikatan Annexin $\mathrm{V}$ sebagai penanda apoptosis tahap awal. 


\section{KESIMPULAN}

Berdasarkan hasil uji sitotoksik dan apoptosis subfraksi ekstrak etil asetat Ulva fasciata Delile terhadap sel kanker serviks (CaSki) dan sel kanker payudara (MCF-7) dapat diambil kesimpulan bahwa:

1. Setiap fraksi etil asetat yang diuji (F1-F9) memiliki potensi sebagai antitumor dengan nilai $\mathrm{IC}_{50}$ pertumbuhan sel CaSki pada konsentrasi 22,23$31,54 \mathrm{ì} \mathrm{g} / \mathrm{ml}$.

2. Setiap fraksi etil asetat dapat menginduksi apoptosis pada sel CaSki dan MCF-7. Persentase apoptosis tertinggi terhadap sel CaSki adalah 3,92\% oleh fraksi 8 (Etil asetat/Etanol, 0/100) dan terhadap sel MCF-7 adalah 12,93\% oleh fraksi F2 ( $n$-heksan/diklormetan, 50/50).

3. Setiap fraksi etil asetat lebih potensial terhadap sel MCF-7 dibandingkan terhadap sel CaSki.

\section{UCAPAN TERIMA KASIH}

Penulis mengucapkan terima kasih yang sangat dalam kepada dr. Abidin Widjanarko, Ph.D. dan Dr. Wan Lelly Heffen, Apt. di Rumah Sakit Kanker DHARMAIS-Jakarta, atas izin dan supervisi penggunaan fasilitas laboratorium dan instrument flowcytometry serta penyediaan sel lestari tumor yang diperlukan.

\section{DAFTAR PUSTAKA}

Anonim. 2010. Statistik Dharmais. http:// www. dharmais.co.id/index.php/cance-statistic. html. Diakses pada tanggal 8 Januari 2010.

Anonim. 2012a. Cervical cancer. www.macmillan.org.uk/ cancerinformation/cancertypes/cervix/ cervicalcancer.aspx. Diakses pada tanggal 16 Februari 2012

Anonim. 2012 ${ }^{\text {b }}$ Cervical cancer. www.cancer.gov/ cancertopics/types/cervical. Diakses pada tanggal 16 Februari 2012.

ATCC. 2010. CaSki. http:/www.atcc.org. Diakses pada tanggal 9 Februari 2010.

ATCC. $2010^{\text {b }}$ MCF-7. http://Www. atcc.org. Diakses pada tanggal 9 Februari 2010.

Atmadja, W.S, Kadi, A., Sulistijo, dan Rachmaniar. 1996. Pengenalan Jenis-jenis Rumput Laut Indonesia. Puslitbang Oseanologi-LIPI. Jakarta. $191 \mathrm{pp}$.

Calbiochem. 2010. Annexine V-FITC Apoptosis Detection Kit II. http://www.calbiochem.com/ pathways. Diakses pada tanggal 10 Februari 2010.

Carballo, J.L., Hernandez-Inda, Z.L., Perez, P., and GarciaGravaloz, M.D. 2002. A comparison between two brine shrimp assays to detect in vitro cytotoxicity in marine natural products (Methodology Article). BMC Biotechnology 2: 1-5.
Chakraborty, K. and Paulraj, R. 2010. Sesquiterpenoids with free-radical-scavenging properties from marine macroalga Ulva fasciata Delile. Food Chemistry. 122 (1): 31-41.

Djamil, R., Soediro, I., dan Ruslan, K. 2009. Telaah fitokimia dan uji hayati pendahuluan Ulva fasciata Delile. Sekolah Farmasi ITB. http://www.bahanalam.fa.itb.ac.id. Diakses pada tanggal 16 Juni 2009.

Dockery, R.N. 2007. Apoptosis. Http://www.cumc. columbia.edu/dept/ps/2007/mcp/old/ transcript02mcp04.pdf. Diakses pada tanggal 14 Februari 2007.

Fotakis, G. and Timbrell, J.A. 2005. In vitro cytotoxicity assays: Comparison of LDH, neutral red, MTT and protein assay in hepatoma cell lines following exposure to cadmium chloride. Toxicology Letters. 160: 171-177.

Hughes, D. and Mehmet, H. 2003. Cell Proliferation and Apoptosis. BIOS Scientific Publishers Ltd. Oxford. 373 pp.

Jha, R.K. and Zi-Rong, X. 2004. Biomedical compounds from marine organism. Marine Drugs. 2: 123-146.

Marraskuranto, E., Fajarningsih, N.D., Januar, H.I., dan Wikanta, T. 2008. Aktivitas antitumor (HeLa dan T47D) dan antioksidan ekstrak makroalga hijau Ulva fasciata. Jurnal Pascapanen dan Bioteknologi Kelautan dan Perikanan. 3(2): 107-112.

Mayer, A.M.S. 1999. Marine Pharmacology in 1998: Antitumor and cytotoxic compounds. The Pharmacologist. 11(4): 159-164.

Nursid, M., Fajarningsih, N.D., Januar, H.I., dan Wikanta, T. 2007. Induksi Apoptosis dan Ekspresi Gen p53 dari Ekstrak Makroalga Turbinaria decurrens pada Sel Tumor HeLa. Jurnal Pascapanen dan Bioteknologi Kelautan dan Perikanan. 2(1): 55-60.

Ormerod, M.G. 2000. Flowcytometry: A Practical Approach. Third Edition. University Press, Oxford. 276 pp.

Rinehart, K.L., Shield, L.S., and Parsons, M.C. 1993. Antiviral substances. In Attaway, D.H. and Zaborsky, O.R. (eds.). Marine Biotechnology, vol I. Pharmaceutical and Bioactive Natural Products. Plenum Press, New York. p. 309-342.

Schmitz, F.J., Bowden, B.F., and Toth, S.I. 1993. Antitumor and cytotoxic compounds from marine organisms. In Attaway, D.H. and Zaborsky, O.R. (eds.). Marine Biotechnology, vol I. Pharmaceutical and Bioactive Natural Products. Plenum Press, New York. p. 197308

Torres, M.R., Sousa, A.P.A., Filho, E.A.T.S., Moraes, M.E.A., Moraes, M.O., and Costa-Laluto, L.V. 2005. Biological activity of aqueous and organic extract of seaweeds from Ceara State, Brazil. Arq. Cien. Mar. Fortaleza 38: $55-63$.

Wikanta, T., Prabukusuma, A., Ratih, D., dan Januar, H.I. 2010. Bioaktivitas ekstrak kasar aseton, fraksi dan subfraksinya dari Ulva fasciata terhadap sel lestari tumor HeLa. Jurnal Pascapanen dan Bioteknologi Kelautan dan Perikanan. 5(1): 1-10. 
Wikanta, T., Handayani, V.F., Rahayu, L., Pratitis, A., dan Wuyung, P.E. 2011. Pengaruh pemberian ekstrak etil asetat Ulva fasciata Delile dan Turbinaria decurrens
Bory terhadap laju pertumbuhan tumor kelenjar susu pada mencit $\mathrm{C} 3 \mathrm{H}$. Jurnal Pascapanen dan Bioteknologi Kelautan dan Perikanan. 6(1): 57-68. 